\section{J.Thi-Qar Sci.}

ISSN 1991- 8690

website: http://jsci.utq.edu.iq
No. (2)

Vol.1

الترقيم الدولي ، 1991 - 199

Email: utjsci@utq.edu.iq

\title{
Assessment of Immunoglobulins In The Serum Of Children With Shigellosis
}

\author{
Dr. Talib Falih Hassen
}

Medical department - Nassiria Technical Institute - Thi -Qar /Iraq

\begin{abstract}
$\underline{\text { Abstract }}$
During a period of nine months from January 2006 to September 2006. Sixty -two cases of shigellosis were collected at Nassiria Pediatric hospital ( Age ranged from one day to five years). A total of 317 cases suffering form bloody diarrhea, out of 317 stool samples, 62 bacterial isolates were obtained represent $19.5 \%$ from all cases of diarrhea ,The isolates identified were, Shigella dysenteriae, Shigella sonnei, Shigella boydii, and Shigella flexneri .The percentage of each are , 22(35.4\%), 19(30.6\%), 13(20.9\%), $\mathbf{8}(\mathbf{1 2 . 9 \%})$ respectively . Shigellosis was predominant in those below one year of age $(32.2 \%)$.The concentration of total protein level in the serum of children with shigellosis was normal in all age groups, while albumin was low , alpha 1 - globulin concentration was high, alpha 2 -globulin increased slightly with advancing age, beta - globulin concentration in serum of children was normal, gamma globulin concentration was slightly elevated in most age groups . Forty - seven children (75.8\%) are found to have high level of Immunoglobulins concentration while fifteen children ( $24.2 \%$ ) have low levels of Immunoglobulin concentration .They are classified as follows : $\mathbf{1 1 . 2 \%}$ have IgA deficiency, $5.1 \%$ have IgM deficiency and $4.8 \%$ have IgG deficiency.These results revealed that Ig deficiency is associated with shigellosis .
\end{abstract}




\section{Introduction:}

Shigellosis (severe bloody diarrhea) is an important cause of diarrheal disease in developing countries [1], and in travelers to tropical countries[2,3]. It becoming one of the leading causes of diarrhea morbidity and mortality in children under five years of age.[4 ]

Four species of Shigella are pathogenic for man. Shigella sonnei and Shigella boydii usually causes relatively mild illness in which diarrhea may be watery or bloody [5 ]. Shigella flexneri is the chief cause of endemic shigellosis in developing countries, and Shigella dysenteriae type 1 causes both epidemic and endemic shigellosis. Although Shigella dysenteriae type 1 is the Shigella species associated with the most severe disease and the highest case fatality rates, the majority of deaths from shigellosis result, from endemic disease, especially that caused by Shigella flexneri [6]. Shigellosis is also more severe in children with pre-existing malnutrition, causing their nutritional status to worsen rapidly [ $4,7,8$ ]. Shigellosis occur in children under five years old.[4 ]

Among children, the risk of death from shigellosis is greatest in infants and those who are severely malnourished [ 9 ]. High case fatality rates (5\% and above) may be associated with any of the four species of Shigella (Shigella dysenteriae type 1, Shigella. Flexneri, Shigella. Boydii and Shigella sonnei) [10 ]. The virulence factors of the lipopolysaccharide of Shigella species bacteria include the endotoxic activities of the lipid A component of the molecule and the ability of the polysaccharide chain-the core and the O-antigenic polysaccharide-to provide the bacterium with resistance to host defense mechanisms such as opsonization, phagocytosis, and intracellular killing [11]. Shigella also invades epithelial cells through pathogen-directed endocytosis [12]. Invasion of enterocytes and bacterial cell-to-cell spread enhance tissue damage [ 13,14 ].

Level of serum protein components, albumin ,alpha1 globulin ,alph2 globulin.beta globulin and gamma globulin were used to diagnosis some diseases by using serum protein electrophoresis .This pattern can provide clues to diagnose some diseases and done to evaluate hypogammaglobulinemia a condition charactrierized by low level of gamma globulin antibodies such as $\mathrm{IgG}$ which is predominant during bacterial infection and the IgA subclass distribution of serum antibodies against different common bacterial ,viral and food antigens.[15 , 16,17 ].The aim of this study to determine the frequency of Shigellosis diseases among children and the effect of this infection on the serum proteins and immunoglobulins levels in the serum of children with shigellosis disease .

\section{Materials and Methods: \\ Patients:}

During the period from January 2006 to September 2006 ,Sixty-two stool and blood samples were obtained from pediatric patients (aged from one day to five years old) whom suffering from bloody diarrhea and shigellosis were included in this study they were admitted to pediatric hospital in Al-Nassiria city . Information obtained at the time of admission included, age ,sex ,antibiotics intake before admission.,.

\section{Control group:}

This group consisted of ten (10) healthy children without any disease 


\section{Microbiological methods:}

To isolate Shigella species, stool samples were inoculated onto MacConkey agar and Salmonella-Shigella agar and the resulting colonies which exhibited characteristics of Shigella species were identified by conventional biochemical methods [18]. The macroscopic examination also were done to determine presence of blood and mucus .

\section{Serum protein electrophoresis:}

Serum were used to determined the fractionations of the serum proteins by cellulose acetate electrophoresis (Beckaman company, CDS-200) [ 19 ] .

\section{Single Radial Immunodiffusion :}

Immunoglobulins were determine by single radial Immunodiffusion method by using ,immuno -kit ( Bio Meruex France ) according to (Goldlum \&goldman,1977).[20 ] .

\section{Results:}

Shigella species are a common cause of bacterial diarrhea in developing countries and the diagnosis of shigellosis was considered when the clinical presentation and examination were suggestive, in addition to laboratory diagnosis .

A total of 317 cases suffering from bloody diarrhea enrolled in the study, out of 317 stool samples , 62 bacterial isolates were obtained represent $19.5 \%$ from all cases of diarrhea, these isolates are distributed as follows : Shigella dysenteriae 22(35.4\%), Shigella sonnei 19(30.6\%), Shigella boydii 13(20.9\%), and Shigella flexneri $8(12.9 \%)$ table (1) .

Table(1 ): Number and percentage of shigellosis cases according to Shigella species

\begin{tabular}{|c|c|c|}
\hline & No. of cases & Percentage \\
Shigella Species & & $\%$ \\
\hline Shigella .dysenteriae & 22 & $\mathbf{3 5 . 4}$ \\
\hline Shigella sonnei & $\mathbf{1 9}$ & $\mathbf{3 0 . 6}$ \\
\hline Shigella boydii & $\mathbf{1 3}$ & $\mathbf{2 0 . 9}$ \\
\hline Shigella flexneri & $\mathbf{8}$ & $\mathbf{1 2 . 9}$ \\
\hline Total & $\mathbf{6 2}$ & $\mathbf{1 0 0}$ \\
\hline
\end{tabular}




\section{J.Thi-Qar Sci. No. (2)}

Table (2) shows the predominance of shigellosis among below one year age group $32.2 \%$ and only nine cases were occur in 2-3 age group represent $14.5 \%$ Shigella dysenteriae was predominance among below one year age group (9 cases) , while only 2 cases were occurred in the
2-3 age group most cases of Shigella sonnei were occurred in 2-3 age group . Shigella boydii was predominance in below one year age group ( 3 cases). most of shigellosis cases in 1-2 age group (4 cases) table(2) .

Table( 2 ) : Relationship between age group of children and Shigella species

\begin{tabular}{|c|c|c|c|c|c|c|}
\hline \multirow{2}{*}{ Shigella species } & \multirow{2}{*}{ Total } & \multicolumn{5}{|c|}{ Age group } \\
\cline { 3 - 7 } & & $\begin{array}{c}\text { Below } \\
\text { one year }\end{array}$ & $1-2$ & $2-3$ & $3-4$ & $4-5$ \\
\hline Shigella.dysenteriae & 22 & 9 & 4 & 2 & 3 & 4 \\
\hline Shigella sonnei & 19 & 5 & 3 & 6 & 2 & 3 \\
\hline Shigella boydii & 13 & 3 & 4 & 0 & 3 & 3 \\
\hline Shigella flexneri & 8 & 3 & 2 & 1 & 2 & 0 \\
\hline Total & $\begin{array}{c}62 \\
(100 \%)\end{array}$ & $\begin{array}{c}(32.2 \%) \\
(20.9 \%)\end{array}$ & $\begin{array}{c}9 \\
(14.5 \%)\end{array}$ & $\begin{array}{c}16.1 \%) \\
(16.1 \%)\end{array}$ \\
\hline
\end{tabular}

Table (3) and fig. (1) shows the concentration of total protein which showed normal level of total protein in all age groups, while albumin was decreased , alpha 1 - globulin concentration in the serum of children with shigellosis was increased while alpha 2 -globulin was increase slightly with advancing age, beta - globulin concentration in serum of children patients was normal, gamma globulin concentration was slightly elevated in most age groups when compared with normal value . 


\section{$\begin{array}{llll}\text { J.Thi-Qar Sci. } & \text { No. (2) } & \text { Vol.1 } & \text { Aug./2008 }\end{array}$}

Table( 3 ) : Concentration of serum proteins in children with shigellosis according to age Groups

\begin{tabular}{|c|c|c|c|c|c|}
\hline \multirow{2}{*}{ Serum Proteins } & \multicolumn{5}{|c|}{ Age group (years) } \\
\hline & Below one year & $1-2$ & $2-3$ & $3-4$ & $4-5$ \\
\hline Total protein & $\begin{array}{c} \pm 6.3 \\
\pm \pm 67 \\
\pm \pm[4-7.6]\end{array}$ & $\begin{array}{c}63 \\
7.0 \\
(5.6-75)\end{array}$ & $\begin{array}{c}6.1 \\
6.5 \\
(5-6-9)\end{array}$ & $\begin{array}{c}7.6 \\
7.1 \\
(5.6-8)\end{array}$ & $\begin{array}{c}7.8 \\
6.9 \\
(5.6-8)\end{array}$ \\
\hline Albumin & $\begin{array}{c}2.5 \\
3.7 \\
(32-5.7)\end{array}$ & $\begin{array}{c}29 \\
4.1 \\
(3.9-5.4)\end{array}$ & $\begin{array}{c}29 \\
3.9 \\
(3.9-6-4)\end{array}$ & $\begin{array}{c}32 \\
42 \\
(3.9-5-4)\end{array}$ & $\begin{array}{c}3.1 \\
4.6 \\
(3.9-5-4)\end{array}$ \\
\hline a-1 glabulin & $\begin{array}{c}0.8 \\
0.3 \\
0.1-03)\end{array}$ & $\begin{array}{c}0.6 \\
0.2 \\
(0.1-03)\end{array}$ & $\begin{array}{c}0.6 \\
0.2 \\
0.1-03)\end{array}$ & $\begin{array}{c}1.4 \\
0.1 \\
(0.1-0.3)\end{array}$ & $\begin{array}{c}1.7 \\
0.3 \\
0.1-03)\end{array}$ \\
\hline a-2 glabulin & $\begin{array}{c}0.6 \\
0.9 \\
(0.2-11)\end{array}$ & $\begin{array}{c}0.7 \\
0.6 \\
(0.4-0.8)\end{array}$ & $\begin{array}{c}0.7 \\
0.8 \\
(0.4-0.8)\end{array}$ & $\begin{array}{c}1.0 \\
0.7 \\
(0.4-0.8)\end{array}$ & $\begin{array}{c}0.9 \\
0.7 \\
(0.4-0.8)\end{array}$ \\
\hline P-globulin & $\begin{array}{c}0.7 \\
0.7 \\
(03-1.0)\end{array}$ & $\begin{array}{c}0.4 \\
0.7 \\
(0.5-10)\end{array}$ & $\begin{array}{c}0.5 \\
0.8 \\
0.5-10)\end{array}$ & $\begin{array}{c}0.6 \\
0.7 \\
(0.5-10)\end{array}$ & $\begin{array}{c}0.8 \\
0.6 \\
(0.5-10)\end{array}$ \\
\hline$\overline{y-\text { globulin }}$ & $\begin{array}{c}12 \\
0.9 \\
(02-12)\end{array}$ & $\begin{array}{c}13 \\
0.7 \\
(0.4-13)\end{array}$ & $\begin{array}{c}1.1 \\
0.8 \\
(0.4-13)\end{array}$ & $\begin{array}{c}19 \\
0.9 \\
(0.4-13)\end{array}$ & $\begin{array}{c}2.1 \\
0.9 \\
(0.4-13)\end{array}$ \\
\hline
\end{tabular}

*The concentration in milligram $/ 100 \mathrm{ml}$

** The concentration in milligram/100

$\mathrm{ml}$ for control group

*** Normal value (Henry et al ,1984),

[21].

Fig.(1): Bands of Serum proteins of children with Shigellosis 


\section{J.Thi-Qar Sci. No. (2)}

Serum concentration of $\operatorname{IgG}, \operatorname{IgM}$ and $\operatorname{Ig} A$ are measured by radial immunodiffusion using partigens supplied by (Bio Mereux France ) .

Forty - seven children patients $75.8 \%$ were found to have high level of lmmunoglobulin concentration while fifteen children patient, $24.2 \%$ have low levels of lmmunoglobulin concentration compared to normal value they are classified as follows : $11.2 \%$ have IgA deficiency , $5.1 \%$ have IgM deficiency and $4.8 \%$ have $\operatorname{IgG}$ deficiency table $[3,4,5]$.

Table ( 4 ): IgG concentration in serum of children with Shigellosis according to age groun

\begin{tabular}{|c|c|c|c|c|c|}
\hline $\begin{array}{l}\text { Age } \\
\text { group }\end{array}$ & Total & $\begin{array}{l}\text { * Normal } \\
\text { conc. } \\
* * \text { (mg/dI) } \\
\mathbf{X} \pm \mathbf{S}\end{array}$ & $\begin{array}{l}\text { Conc. Of IgG } \\
(\mathrm{mg} / \mathrm{dl})\end{array}$ & $\begin{array}{c}\text { Conc. Of IgG } \\
\begin{array}{c}(\mathrm{mg} / \mathrm{dl}) \\
\mathrm{X} \pm \mathrm{S}\end{array} \\
\text { Patients }\end{array}$ & $\begin{array}{c}\text { "P" } \\
\text { Value }\end{array}$ \\
\hline $\begin{array}{l}\text { Below one } \\
\text { year }\end{array}$ & 20 & $661 \pm 219$ & $603 \pm 211$ & $787.8 \pm 362.7$ & $P<0.001$ \\
\hline $1-2$ & 13 & $762 \pm 209$ & $821 \pm 228$ & $846.2 \pm 392.4$ & $P<0.001$ \\
\hline $2-3$ & 8 & $929 \pm 228$ & $960 \pm 219$ & $1034.4 \pm 387.3$ & $P<0.001$ \\
\hline $3-4$ & 10 & $929 \pm 228$ & $930 \pm 231$ & $1125.3 \pm 283.7$ & $P<0.001$ \\
\hline $4-5$ & 11 & $929 \pm 228$ & $941 \pm 223$ & $1239.8 \pm 272.6$ & $P<0.001$ \\
\hline
\end{tabular}

* Maxwell et al ,1976, [ 22 ]. * ** dl: decilitre

Table ( 5 ) : IgM concentration in serum of children with Shigellosis according to age group

\begin{tabular}{|c|c|c|c|c|c|}
\hline Age group & Total & $\begin{array}{l}\text { Normal } \\
\text { conc. } \\
(\mathbf{m g} / \mathbf{d l}) \\
\mathrm{X} \pm \mathrm{S}\end{array}$ & $\begin{array}{c}\text { Conc. Of IgMI } \\
(\mathrm{mg} / \mathrm{dl}) \\
\mathbf{X} \pm \mathbf{S} \\
\text { Control group }\end{array}$ & $\begin{array}{c}\text { Conc. Of IgMI } \\
(\mathbf{m g} / \text { dl }) \\
\mathbf{X} \pm \mathbf{S} \\
\text { Patients }\end{array}$ & $\begin{array}{c}\text { "P" } \\
\text { Value }\end{array}$ \\
\hline $\begin{array}{c}\text { Below one } \\
\text { year }\end{array}$ & 20 & $43 \pm 17$ & $48 \pm 11$ & $54.7 \pm 17.7$ & $\begin{array}{c}\mathbf{P}< \\
0.001\end{array}$ \\
\hline $1-2$ & 13 & $58 \pm 23$ & $59 \pm 21$ & $58.4 \pm 39.2$ & $\begin{array}{c}\mathbf{P}< \\
0.001\end{array}$ \\
\hline $2-3$ & $\mathbf{s}$ & $56 \pm 18$ & $57 \pm 15$ & $134.4 \pm 387.3$ & $\begin{array}{c}\mathbf{P}< \\
0.001\end{array}$ \\
\hline $3-4$ & 10 & $56 \pm 18$ & $58 \pm 12$ & $132.5 \pm 28.7$ & $\begin{array}{c}\mathbf{P}< \\
0.001\end{array}$ \\
\hline $4-5$ & 11 & $56 \pm 18$ & $56 \pm 17$ & 139. $6 \pm 72.2$ & $\begin{array}{c}\mathbf{P}< \\
0.001\end{array}$ \\
\hline
\end{tabular}

* Maxwell et al ,1976 
Table (6 ): IgA concentration in serum of children with Shigellosis according to age group

\begin{tabular}{|c|c|c|c|c|c|}
\hline Age group & Total & $\begin{array}{c}\text { Normal } \\
\text { conc. } \\
\text { (mg/dl) } \\
\mathrm{X} \pm \mathrm{S}\end{array}$ & $\begin{array}{c}\begin{array}{c}\text { Conc. Of IgA } \\
(\mathrm{mg} / \mathrm{dl}) \\
\mathrm{X} \pm \mathrm{S}\end{array} \\
\text { Control group }\end{array}$ & 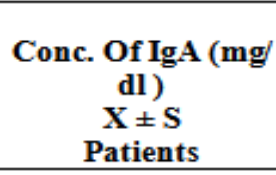 & $\begin{array}{c}\text { "P" } \\
\text { Value }\end{array}$ \\
\hline $\begin{array}{c}\text { Below one } \\
\text { year }\end{array}$ & 20 & $37 \pm 18$ & $38 \pm 12$ & $18.6 \pm 16.2$ & $\mathrm{P}<0.001$ \\
\hline $1--2$ & 13 & $50+24$ & $52 \pm 18$ & $43.3 \pm 13.2$ & $P<0.001$ \\
\hline $2-3$ & 8 & $50 \pm 24$ & $50 \pm 21$ & $104.6 \pm 37.8$ & $\mathrm{P}<0.001$ \\
\hline $3--4$ & 10 & $93 \pm 27$ & $95 \pm 19$ & $112.3 \pm 28.7$ & $\mathrm{P}<0.001$ \\
\hline $4--5$ & 11 & $93 \pm 27$ & $93 \pm 22$ & $129.3 \pm 77.5$ & $\mathrm{P}<0.001$ \\
\hline
\end{tabular}

* Maxwell et al ,1976

\section{Discussion :}

Four species of shigella are pathogenic for man . Shigella dysenteriae causes both epidemic and endemic shigellosis, and this bacterium associated with the most severe disease and the highest case fatality rates [ 10 ]. Shigella sonnei and Shigella boydii usually cause relatively mild illness in which diarrhea may be watery and bloody [ 5 ] .Shigella flexneri . is the chief cause of endemic shigellosis in developing contries [10,23 ]. The study showed that the percentage of shigllosis among children $19.5 \%$ from all cases of diarrhea . these result go with [ 24 ] . in this study we found Shigella dysenteriae was predominance cause of shigellosis, while in Egypts Nile Delta the Shigella flexneri being the most common isolated from children less than three years [25].

During the past 30 years, pandemics of Shigella dysenteriae have spread across central America , Bangladesh , South Asia and Central and East Africa
[ 26, 27, 28 ] less frequency of Shigella species in this study was Shigella flexneri while Shigella flexineri is the main serogroup found in developing contries median 60\% [ 29 ] in our study Shigella sonnei was the second cause of shigellosis this result go with other report[30] . followed by Shigella boydii and Shigella flexneri :[30]. Most of shigellosis cases were found in below one year age group a similar result had been found in study conducted by [30, 31]. among children the risks of death from shigellosis is greatest in infant and those who are severely malnourished [ 9 ].

Our results showed the concentration of the total protein in serum of children with shigellosis, generally was in the normal level in all age groups, while its increase slightly with advancing age but the concentration of the total protein was still in the normal range in each age group, this result go with [ 32 ]. Albumin concentration was found decreased when compared with normal levels, similar 
result was found by [ 33 ].Decreased serum albumin may result from liver and kidney diseases which allows albumin to escape into urine, while an increase in the percentage of albumin can indicate a severe loss of water from the bloodstream[ 34]. Albumin concentration was decreased in children with bacterial meningitis whom under five years old [32] . The second component of serum protein is globulins, the globulins are roughly divided into alpha ,beta ,and gamma globulins, alpha globulins include alpha 1 globulin and alpha 2 globulin [ 34 ]. Alpha 1 globulin was increased in all age groups, similar result was observed by[ 32 ] , and this may be due to complement concentration which is occur according to the infection, while alpha 2 globulin concentration was normal range in most age group this result go with [32 ]. Beta globulin concentration was normal an increase in the percentage of beta globulin may caused by liver disease, while the decrease of beta globulin level may caused by kidney disease or a problems with blood clotting process. Gamma globulin was increased in all age groups this result was expectant due to immune response according to bacterial invasion, the an increase in the level of gamma globulin may be caused by a chronic infection [ 34] , while a decrease in the percentage of gamma globulin may be caused by kidney disease or a problems of the immune system. Serum concentration of IgG, IgM, and $\operatorname{Ig} \mathrm{A}$ were measured by radial immundiffusion and our result showed that $75.8 \%$ of children patients with shigellosis have high level of immunoglobulins, while $24.2 \%$ have low level of immunoglobulins, this immune deficiency may due to problems in the immunity system this result go with [32 ]
Some diseases

cause hypogammaglobulinemia ( acondition characterized by low level of gamma globulin antibodies such as $\mathrm{IgG}$ which predominant during infection and $\operatorname{IgA}$ which is distribution of serum antibodies against different common bacterial, viral , and food antigens [ $15,16,17$ ].

The IgG, IgM and IgA deficiency lead to response to infection. The changes in IgM levels in patients were significantwhen compared with control group and normal range, so $\mathrm{IgG}$ and $\mathrm{IgA}$, and this may be due to invasion by gram negative bacteria or due to poor diet (malnutrition) and gastrointestinal. Which caused by Shigella species. [ 20 ] . Shigellosis induced a rise of anti-LPS of all three $\mathrm{Ig}$, the increase in $\mathrm{IgG}$ is the highest and has the longest duration (35 36). The Ig response is related to the severity of symptoms, and anti-LPS levels of the three Ig types decline to those in acute-phase sera in less than 1 year (36, 37). . The higher and longer-lasting levels of $\mathrm{IgG}$ suggest that our conjugates will induce a more complete and long-lasting immunity than shigellosis.[36] 


\section{References:}

1-Division of Health Promotion and Disease Prevention and Division of International Health, Institute of Medicine. The burden of disease resulting from various diarrheal pathogens, appendix C. In New vaccine development: establishing priorities, vol. II. Diseases of importance in developing countries. National Academy Press, Washington, D.C. 1986.

2-Tauxer, R., N. D. Puhr, and J. G. Well.. Antimicrobial resistance of Shigella isolates in the USA: the importance of international travelers. J. Infect. Dis. 162:1107-1111. 1990

3-Vila, J., J. Gascón, S. Abdalla, J. Gomez, F. Marco, A. Moreno, and M. Corachán.Antimicrobial resistance of Shigella isolates causing traveller's diarrhea. Antimicrob. Agents Chemother. 38:26682670. 1994.

4- The burden of disease resulting from diarrhea. In Katz, S.L., ed. New Vaccine Development: Establishing Priorities. Vol. 2. Diseases of Importance in Developing Countries. Washington: National Academy Press, 165 ,1986.

5- Keusch, G.T. \& Bennish, M.L. Shigellosis: recent progress, persisting problems and research issues. Pediatr Infect Dis J 8:71319.1989.

6- Bennish, M.L. \& Wojtyniak, B.J. Mortality due to shigellosis: community and hospital data. Rev Infect Dis 13(Suppl 4):S245-S251 .1991 .

7- Bennish, M.L. Potentially lethal complications of shigellosis. Rev Infect Dis 13(Suppl 14):S319- S324 .1991.

8- Briend, A.; Dykewicz, C.; Graven, K; Mazumder, R.N.; Wojtyniak, B. \& Bennish , M. Usefulness of nutritional indices and classification in predicting death of malnourished children. $\mathrm{Br}$ Med. J. 293:373-375.1986.

9- Bennish, M.L., Harris, J.R., Wojtyniak, B.J. \& Struelens, M. Death in shigellosis: incidence and risk factors in hospitalized patients. $J$ Infect Dis 161:500-506 .1990.
10. Bennish, M.L. \& Wojtyniak, B.J. Mortality due to shigellosis: community and hospital data. Rev Infect Dis 13(Suppl 4):S245-S251. 1991.

11- Lindberg ,A.A. ; Karnell ,A. and Weintraub,A. The lipopolysacchride of shigella bacteria as avirulence factor . Rev. Infect. Dis. 13 suppl 4:279 -284. 1991.

12-Ménard, R., C. Dehio, and P. J. Sansonetti. Bacterial entry into epithelial cells: the paradigm of Shigella. Trends Microbiol. 4:220-226 .1996.

13-LaBrec, E. H., H. Schneider, T. J. Magnani, and S. B. Formal. Epithelial cell pentetration as an essential step in the pathogenesis of bacillary dysentery. J. Bacteriol. 88:15031518.1964.

14-Sansonetti, P. J., and Arondel, J. Construction and evaluation of a double mutant of Shigella

flexneri as a candidate for oral vaccination against shigellosis. Vaccine 7:443-450 .1989.

15- Hammarstrom ,L.M.; Person, A.A. and Smith,C.I. IgG a nd IgA subclass distribution of human anti $\mathrm{S}$. aureus alpha toxin antibodies : suggestion of an IgG1,IgA1,IgG4 switch Pattern. Scand. J. Immunol. 20:247. 1984 .

16- Lowry , O . H .; Rosebrough , N . J . ; Farr , A . L . and Randall , R . J . Protein measurement with the Folin phenol reagenl . J . Biol . Chem . 193 : 267 - 275 . 1951

17- Russel , M . W .; Hammond , D . J .Radl , .; Haaijman , J . and Mestecky, J . Secretory $\operatorname{IgA} 1$ and $\operatorname{IgA} 2$ responses to environmental antigens . protides Biol. Fluids $32: 77-80$. 1984.

18- Brooks , G . F . ; Butel , J . S.; and Morse , S. A . : Jawetz, Melnick and Adelberg s Medical Microbioloy . 21 ed . Appelton and Lange. 2004.

19- Hassen T. F. Bacteriological, Serological and Chemical study of cerebrospinal fluid in children with meningitis from Baghdad city ,Master Thesis submitted to the college of 
Science, Al- Mustansiriyah Univ. p 27 -28. 1998.

20-Goldman ,A.S. and Goldbium,R.M. Primary deficienciesin humoral immunity. Pediatr.

Clin.N.Am. 24:280. 1977.

21- Henry ,C.K . Current pediatric diagnosis and treatment. 8 ed. Lange medical publications. 1984 .

22- Maxwell ,M. Clinical Hematology, 7 ed. Lea and Febiger publication .1976.

23- Bennish, M.L., Azad, K.M., Rahman, O. \& Phillips, R.E. Hypoglycemia during diarrhea in childhood. New Engl J Med 322:1357 13631990 .

24. Centers for Disease Cotrol . Multiply resistant shigellosis in a day - care centre - - Texas . MMWR : $35: 753$ - 5. 1986.

25- Remon R .;Abu - Ely Azeed ; Thomas F . ;Wierzba, Robert W.; Frenck, Shannon D.;Putnam , Malla R.; Rao , Stephen J.Savarino, Karim A . Kamal, Leonard F . ;Peruski , JR . ; Ibrahim A .;Abd - El Messih ; Sahar A . ;El- Alkamy, Abdoliah B .Naficy, and John D . Clemens .Epidemiology of shigella - associated diarrhea in rural Egyptian children $A m . J$ .Trop. Med. Hyg ., 71 (3), pp . $367-372$, 2004.

26- Centers for Disasse Cotrol and prevention . Health status of displaced persons following Civil War - - Burundi, December 1993 - January 1994. MMWR :43:701-3 . 1994.

27- Gangarosa EJ , Perera DR , Mata LJ , Mendizabal - Morris , C , Guzman G , Reller LB . Epidemic Shiga bacillus dysentery in Central America . II . Epidemiologic studies in 1969 . J Infect. Dis. : $122: 181-90.1970$.

28 - Rahaman MM , Khan MM , Aziz KMS , Islam MS , Kibriya AK. An outbreak of dysentery caused by Shigella dysenteriae type 1 on a Coral Island in the Bay of Bengal . J. Infect. Dis. : $132: 15$ - 9. 1975.

29- Kotloff, KL .; Winickoff JP. And Ivanoff , B . Global burden of Shigella infections
:Implications for vaccine development and implementation. Bull WHO : 77(8):65166. 1999.

30- Huskins, C.W.; Griffiths, J.K., Faruque, A.S.G. and Bennish, M.L. Shigellosis in neonates and young infants. J Pediatrics (1994, in press).

31 . Ferreccio C,Prado V,; Ojeda , A . Epidemiologic patterns of acute diarrhea and endemic Shigella infections in a poor periurban setting in Santiago, Chile. Am .J. Epidemiol .: $134: 614$ - 27. 1991.

32- Al-Dahan,M.A. Immunoglobulins deficiency In Children With Bacterial Meningitis, Master Thesis submitted to the college of Science, Al-Mustansiriyah Univ. pp 84 -92. 1993.

33- Wallach , J. Interpretation of diagnostic test .3 ed. Boston little, Brown compony .1987

34-http:// www . webmd . com / hw / health _ guide _ atoz / hw43650 asp

35. Cohen, D., C. Block, M. S. Green, G. Lowell, and I. Ofek. 1989. Immunoglobulin M, A, and $G$ antibody response to lipopolysaccharide $\mathrm{O}$ antigen in symptomatic and asymptomatic Shigella infections J. Clin. Microbiol. 27: 162167.Immun. 64:2709-2715.

36. Cohen, D., M. S. Green, C. Block, T. Rouach, and T. Ofek. 1988. S erum antibodies to lipopolysaccharide and natural immunity to Shigellosis in an Israeli military population. J. Infect. Dis. 157:1068-1071.

37. Mackowski, P. A., S. S. Wasserman, and M. M.Levine. 1993. Relationship between humoral immune responses and oral temperature during human shigellosis. J. Infect. Dis. 167:1449- 1452. 


\section{$\begin{array}{llll}\text { J.Thi-Qar Sci. } & \text { No. (2) } & \text { Vol.1 } & \text { Aug./2008 }\end{array}$}

تقييم الكلوبيولينات المناعية في مصل الاطفال المصابين بداء الشيغلات

\section{Talib Falih Hassen}

Medical department - Nassiria Technical Institute - Thi -Qar /Iraq

\section{الخلاصة}

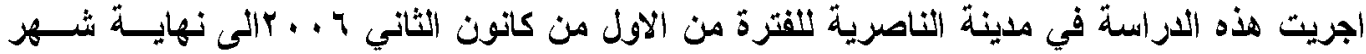

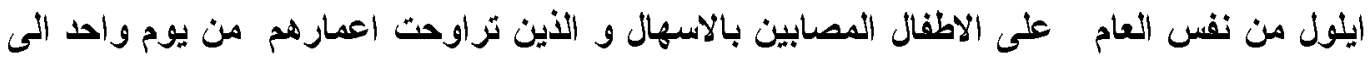
خمس سنوات. تم فحص VIV عيذة غائط ممن كانوا يعانون من الاسهال الاموي ووجد من خـلال هذه الدراسة ان نسبة الاطفال المصابين بداء الثيغلا هو ه,19 \% وكان عدد العزلات كما يساتي :

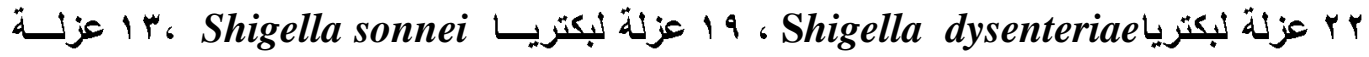
لبكتريا Shigella boydii ، و م عزلات لبكتريا Shigella flexneri ـ اوضــت الثراسـة ان نسبة الاصابة في الفئة العمرية (اقل من سنة ) كانت اعلى مماهو علية في الفئات العمرية الاخــرى.

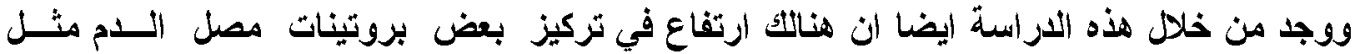
albumin و و alpha 1 - globulin دون مستوياتة الطيعية ويقي تركيز البروتين الكلي عند مستو اه الطبيعي وفي كل الفئات العمريسـة . ووجد ايضا ان هنالك عوز مناعي عند الاطفال المصابين بداء الثيكلا اذ وجد ان هنالك عوز بنسبة

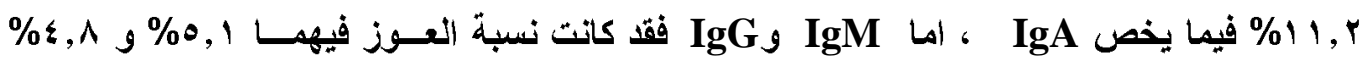

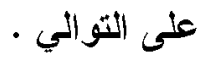

